\title{
EGY MAGYARORSZÁGI TERVEZÉSI VERSENY TANULSÁGAI
}
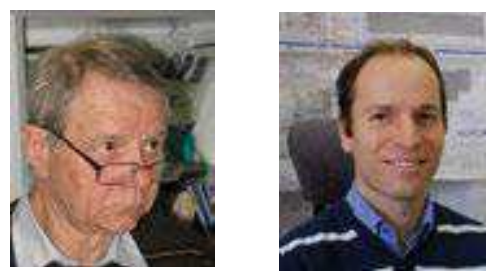

Dr. Almási József - Varvasovszky Péter

Irásunk arra kíván rávilágítani, hogyegy felelös ajánlat elkészítése mekkora szellemiés anyagi eröfeszitéseket kíván, szemben az általános megbizói hiedelemmel „... ugyan, szorozd meg ennyivel a területet és megkapod a tervezési díjat...", amit általában a díjszabások is ösztönöznek, fel nem tárva eléggé részletesen a tervezési feladat elvégzéséhez szükséges müszaki tartalmat.

Tanulság lehet, hogy nem kellöen meghatározott tervezési feladatnál az ajánlatadással bánjon óvatosan a tervezö. Manapság egyre gyakoribb feladat a meglévö épületek funkcióváltásához (átépitéséhez) kapcsolódó tervezési feladat, melyeknél a beruházók a feladat indításnál nem alakitanak ki kellö képet az óhajtott célról, nincsen elegendö információjuk az építményröl.

Kulcsszavak: tervezés, verseny, ajánlat, komplex tervezési feladat, beruházó feladata, müszaki tartalom

\section{BEVEZETÉS}

Bizonyára számos tervezőiroda hasonló esetről tudna beszámolni, mi ezt most megtesszük, hogy részben másokat is inspiráljunk, részben a tanulságokat közkincsé tegyük.

A közelmúltban részt vettünk egy magyarországi tervezési versenyben, azaz több tervezőirodával egyetemben egy tervezési feladat elnyeréséért pályáztunk, egy transzmissziót (pl. egy hengersort) meghajtó villanymotor cseréje kapcsán ( $\mathrm{G}=150$ tonna).

A tervezési feladat komplexitását az alábbiak jellemezték:

gépészmérnöki feladatok:

- a meglévő - mintegy 40 éves - hajtásszekrény és tengelykapcsoló terhelhetőségének (erőátviteli képességének) ellenőrzése,

- a meghajtó villanymotor kenési és hütési rendszerének megoldása, a szükséges vezeték és építmény rendszerrel építőmérnöki és építészeti feladatok:

- a régi gépalap felhasználásával - a korábbi motortól kissé eltérö méretü - villanymotor - új gépalapjának tervezése,

- a villanymotor álló és forgórészének helyszíni összeépítésére szolgáló emelőgerenda megtervezése és a gép mozgatására rendelkezésre álló 50 éves darupálya felülvizsgálata és segéd alátámasztó szerkezet megtervezése/megerősítése, mivel az emelendő súly a daru teherbírását meghaladta,

- új trafóépület tervezése,

- a villanymotor beszállításához új kapunyílás kialakítása a meglévő csarnokban,

- a folyamatirányítás számára csarnokon belüli épületrész kialakítása,

villamosmérnöki feladatok:

- az új gép villamos meghajtásának kialakítása a korábbi villamos al- állomásokról, illetve trafó elemek átalakításával,

- a villamos gép működésének a meglévő folyamatszabályozási rendszerbe való illesztés tervezése,

- alacsony feszültségü rendszerek tervezése,

egyéb feladatok:

mindezen tervezési feladatok végrehajtására szolgáló orga- nizációs, szerelési tervek meghatározása, hogy a gépcsere az évi 1,5 hónapos karbantartási időben elvégezhető legyen,

- árazott költségbecslés, és árazatlan költségvetési kiírás készítése minden munkára,

- kapcsolódó hatósági engedélyek megszerzése.

Az előbbiekben röviden vázolt komplex tervezési feladat „kiírását” a Beruházó egy 3 oldalas levélben sorolta fel. A levél formai kialakítása nem tette lehetővé, hogy az ajánlatot olyan módon állítsuk össze, hogy az a későbbiekben egyszerü hivatkozásokat tegyen lehetővé (pl. a feladatok beszámozása stb.), tehát egy ilyen összetett tervezési feladatot egy „laza tervezési kiírásban" kívánta a pályázókkal megismertetni. [Mint tudjuk: mennél pontatlanabb az elvárás, annál több az ajánlkozónál a bizonytalanság, és így természetes a magasabb ár.]

\section{A TERVEZÉSI VERSENY ÉS A TER- VEZÉS MINŐSÉGE}

A mi felfogásunk szerint a tervezés szellemi és kreativitást kívánó alkotó folyamat, melynek során a tervező elméleti és gyakorlati ismereteit rendszerbe állítva törekszik a feladat optimális megoldására. Nagy valószínüséggel egy-egy feladat megoldása során a tervezők nem azonos megoldásra jutnak. Ez a megállapítás a tervezési ajánlat kidolgozására is fennáll müszaki tartalomtól és tervek kidolgozási szintjétöl függően. A tervezési folyamatot és minöségét nagyban befolyásolja:

- a beruházói elképzelések minél pontosabb meghatározása, a feladat elökészítés pontatlansága vagy pontossága, a helyes cél kijelölése,

- a rendelkezésre álló kiindulási adatok és azok megbízhatósága,

- a tervező „tájékozottsága”, tapasztalata, tudása, a tervezési munka kidolgozásának igényessége,

- a tervező innovációra való képessége, a tudomány mai állásának ismerete.

A tervezési verseny során általában a Beruházó nem gondolja saját magát „versenyeztetni”, pedig akarva, akaratlanul részt vesz benne azzal, hogy milyen információkat, felhívást, válaszokat stb. tesz közzé. A tervezők által feltett kérdések segíthetik a Beruházót, mintegy „kiokosíthatják”, hogy milyen 
legyen a feladat pontosabb megfogalmazása, értelmezése jól kiegészítheti a tervezési cél meghatározását. Egy „érzékeny” Beruházó már itt észrevehetné, vagy megkezdhetné a „tervezők minősítését".

Afeladat értelmezése és az ajánlat kidolgozása, amely alapos esetben a megoldások fö részeinek, az elvégzendő feladatok mennyiségének meghatározása, a szükséges tájékozódás és előkészület a feladat megoldására már jelentős erőfeszítéseket kíván a tervezőktöl és az így kidolgozott „,ajánlat” - ami az áron túlmenően mindig müszaki tartalommal is párosul - komoly ajánlattevő esetében már egy fontos szellemi termék, amelynek „eltulajdonítását” a Beruházó természetesnek véli. Az ajánlat kidolgozása két hónapot vett igénybe, ennek során a Beruházó két alkalommal újra értelmezte a „kiírást”. A Beruházóhoz intézett e-mailek száma elérte a 25-öt. A személyes tárgyalások, utazások összesen $4+2$ mérnöknapot jelentettek, nem beszélve az írott anyag összeállításáról.

A konkrét tervezési verseny esetében a bevezetöben felsorolt komplex feladatokat táblázatos formában, egy-két soros leírással „pontosították”, amiről úgy gondolta a Beruházó, hogy egy-egy feladatrészt most már pontosan leírt és az egyes tervezői feladatok mellé csak ajánlati árat szükséges írni [Így tesz a Beruházó ha csak az ár érdekli és kevésbé a melléje rendelt müszaki tartalom]. Cégünk ezzel nem elégedett meg, hanem részletező magyarázatot és tartalmi megoldásokat adott ajánlatában. Tehettük ezt azért is, mert minden szakági tervező részletes tervezési munkaprogramot dolgozott ki. Csak „,kiszivárogtatott” hírekből tudjuk, hogy ajánlatunk müszaki tartalma, kidolgozottsága a legjobb volt. (Mint utóbb kiderült, a „legmagasabb” árú is egyben, amit természetesnek lehet tartani, hiszen részletesen átgondolt munkaprogram állt mögötte, felmérve a szükséges szellemi és fizikai munkamennyiséget egyaránt és azt a felelősséget, hogy a rendelkezésre álló rövid kivitelezési idő nem teszi majd lehetővé a „hibás” terv javítgatását, biztos megoldások, egymásra épülő lépések sorának megtervezése tökéletes kell legyen, mert az üzem termelésének kiesése többszörös károkat okozhat). A Beruházói kírás ,pontosításához” az is hozzá tartozott volna, hogy a kiinduló adatokat pontosítja, azaz meglévő üzemről, gépekről stb. lévén szó, a rendelkezésre álló terveket, leírásokat is át kellett volna adni. Erre mindig csak ígérgető utalások voltak, illetve az ajánlattevő vegye be az ajánlatába, hogy ha szükséges, felmérésekkel egészíti ki az adatokat, ennek mennyisége teljes bizonytalanságot okozott az ajánlat adásnál [Tipikus eset manapság, hogy lehet bizonytalanságban tartani az ajánlattevőt.]

A Beruházói döntések késlekedése, az ajánlati kiírás müszaki előkészítetlensége már a tervezési felhívás elindítását is késleltették, de úgy gondolták, hogy az itt elvesztegetett időt majd a tervezőkön, azaz a tervezés időtartamának lerövidítésével lehet bepótolni. Ekkor a tervezési feladat elvégzésére három nyári hónapot szántak, amikor egyébként is nehezebb elörelátóan szervezni a munkát [hiszen a magyar tervezők zömének még mindig csak a hazai pihenés-szabadságolás adatik meg, ami a klimatikus viszonyaink között a nyárra esik, és nem teszi lehetővé ezek könnyü áthelyezését az őszre, télre hogy azokat más „földrészeken” töltse a magyar tervező.]

A Beruházó még a tervezési feladatokat pontosító tárgyalások során is ragaszkodott ezen szükös határidőhöz, míg a végén „,belátta”, hogy ezt legalább négy hónapra kell emelni. A Beruházó azt mondta, ,a tervezőnek joga van a hétvégeken és éjjel is dolgozni”, ez természetes, csak azzal nem számolt, hogy kifáradt emberek nem képesek megfelelő teljesítményt és minőséget nyújtani munkájukban. [Cégünk alakulása óta tartjuk azt az elvet, hogy más irodába ,maszekolni” nem lehet, mi fizessünk annyit, hogy a heti munkaidővel a szükséges kereset álljon rendelkezésre. Úgy hisszük, korábban ez teljesült is - 12., 13., sőt 14. havi fizetésekkel - ma már sajnos más a helyzet.]
Sajnálattal kell megállapítani azt is, hogy a magyarországi tervezői versenyek leginkább árversennyé degradálódtak és a minőség versenye - melynek elbírálásához sokkal több energiát kell befektetni a Beruházónak - nem szempont kellő mértékben.

Jelen esetben is úgy gondolta a Beruházó, hogy a tervezési feladatokat végül sikerült „,táblázatos formába" átfogalmazni, és ezek elfogadása a tervezők részéről - egyben a tervezők ajánlatait azonos „minőségi szintre is emelte”, holott pl. a referenciák összevetése és az ajánlatok kidolgozottsága másról is árulkodik(hat). Az ajánlatok kidolgozottságának mélysége szintén jellemezheti az ajánlkozókat, volt, aki csak a „laza kiírásra” egy számot, vagy egy-egy szakág tervezési díj összegét adta meg, a müszaki tartalom részletezése nélkül, illetve az egyes szakágakon belüli ugyan, de részfeladataiban mégis jelentős eltérést mutató tevékenység árainak részletezése nélkül. [Az ajánlattevő is bizonytalanságban tartotta a Beruházót, viszonosság elve.]

Mindezek az információk csak , kiszivárogtatással” jutnak el a résztvevőkhöz, mert - tudomásunk szerint - nincsenek egységes szabályozások az ilyen tervezési versenyek lebonyolítására, a Beruházó „érdeke” sem abban az irányba mutat - bár etikailag ez elvárható lenne -, hogy minden pályázót azonos információkkal lásson el a versenyeztetés folyamán.

Végeredményben a Beruházó a tervezői pályázat és ajánlatok alapján nem tudott (vagy nem akart) dönteni, ezért ,,versenydíjtárgyalást" hívott össze. A három pályázó - a bevezetőben említett feladatokra - a következő díjakat ajánlotta utolsó ajánlatként:

\section{6,5 mill. Ft; $\quad 62,0$ mill. Ft és 52,0 mill. Ft nettó.}

A Beruházó ezt követően közölte, hogy ő is „kalkulált” és erre a tervezésre mindössze 35,0 mill. Ft-ot tud elfogadni. Akarja-e valaki ezért a díjért a feladatot elvégezni, kérdezte. Erre a válasz az volt, hogy nem. A versenytárgyalás így eredmény nélkül ért végett.

Cégünk az ajánlat kidolgozásával két hónapon keresztül foglalkozott, a felmerült költségek 23 nap x $60 \mathrm{eFt}=1,3$ mill $\mathrm{Ft}+200$ eFt utazások, tehát összesen elérték az 1,5 mill Ft-ot.

Úgy szintén költségek jelentkeztek a jövendőbeli altervezőknél, akik a helyszínen is jártak, ajánlatokat előkészítettek, ezek is legalább kitesznek 700 eFt-ot.

Manapság ez teljesen természetes a Beruházónak, hogy ilyen nagyságú költségeket az ajánlkozókra hárítanak, miközben az ajánlatokból „számos szellemi információt” kapnak.

Dr. Almási József (1940) okl. építőmérnök (1964), müszaki doktor (1972), 29 évi kutatás a BME Vasbetonszerkezetek Tanszékén, több mint 200 szakvélemény készítője, 1995 óta a CAEC Kft, 2002 óta az APSE Kft. ügyvezetője. 2002-ben Palotás László-díjat kapott. A BME címzetes egyetemi docense.

Varvasoszky Péter (1977) okl. építőmérnök (2001), partner és vezető tervező az APSE Kft-nél, számos irodaház, bevásárlóközpont, ipari épület statikus tervezője. Fő érdeklődési területe a tartószerkezetek tervezése földrengéses hatásokra.

\section{A LESSON ABOUT A HUNGARIAN DESIGN COMPETITION.}

\section{József Almási - Péter Varvasovsky}

Keywords: design, design offer competition, investor task, complex design task The article (contribution) should like to show, what that to prepare a responsible design offer a large intellectual and financial effort is required, on the contraire that the clients are believing .... please multiplied the area with a number and you get the design fee ... which method are stimulated in most design fee codex too and not go deep in the necessary technical contents which are requirements to give a reasonable (well - founded) offer.

It can be a lesson from this bid competition, if the design task is not well defined, the designer shall be carefully to give an offer. Today is very frequent task to refurbishment existing buildings combined with new function, where the Investor mostly has no clear picture at the beginning what can be the favourable solution for him and this causes a lot of uncertainty, at the and with much more design work, if you have no sufficient information about the building and about the task. 